\title{
Clinical characteristics and laboratory findings of children and adolescents with diabetes
}

\author{
Se Young Kim ${ }^{1 *}$, Eun Young Kim², Jin Soon $\mathrm{Hwang}^{3}$ \\ From 7th APPES Biennial Scientific Meeting \\ Nusa Dua, Bali. 14-17 November 2012
}

The incidence of childhood type 2 diabetes mellitus $(\mathrm{DM})$ is increasing worldwide in parallel with an increasing prevalence of childhood obesity. We investigated the type of diabetes and the clinical characteristics in the newly diagnosed diabetic children.

Retrospective analysis of clinical characteristics was done in 125 newly diagnosed diabetic children and adolescents under 18 years of age in Korea from March 2003 to December 2010. Children diagnosed with type 1 diabetes were 100 out of $125(80 \%)$ and 25 out of $125(20 \%)$ were type 2 diabetes. Mean age of onset was $9.26 \pm 0.99$ years and there was no seasonal variation of incidence. $32 \%$ of children with type 1 diabetes presented initially with diabetic ketoacidosis. Mean body mass index (BMI) was $16.8 \pm 3.8 \mathrm{~kg} / \mathrm{m}^{2}$, mean blood glucose level was $457.6 \pm 212.5 \mathrm{mg} / \mathrm{dL}$ and mean glycated hemoglobin (HbA1c) level was $12.1 \pm 2.28 \%$. Positive result was revealed in $52 \%$ of the subjects with type 1 diabetes for antibodies to glutamic acid decarboxylase (GAD), 3\% for islet-cell antibodies (ICA), 25\% for insulin autoantibodies (IAA) and 63\% showed positive results for at least one of these autoantibodies. 25 patients $(20 \%)$ were diagnosed with type 2 diabetes. Mean age of onset of type 2 diabetes was $12.2 \pm 3.4$ years. 12 out of $25(48 \%)$ subjects were diagnosed with type 2 diabetes in the process of evaluating the cause of obesity without any other presenting symptoms. Mean BMI was $28.3 \pm 8.7 \mathrm{~kg} / \mathrm{m}^{2}$, mean blood glucose level was $217.7 \pm 105.5 \mathrm{mg} / \mathrm{dL}$ and mean HbA1c concentration was $9.0 \pm 2.9 \% .52 \%$ of the subjects diagnosed with type 2 diabetes had a family history of diabetes and $80 \%$ were either overweight or obese. Although still not as common as type 1 diabetes among children, type 2 diabetes mellitus increasingly has been seen in children. Routine medical screening in obese children

'Bundang Jesaeng General Hospital, Daejin Medical Center, Seongnam, Korea

Full list of author information is available at the end of the article and adolescents or ones with other risk factors of type 2 diabetes should be emphasized to make early diagnosis and start management of type 2 diabetes to improve long-term outcomes.

\section{Authors' details}

'Bundang Jesaeng General Hospital, Daejin Medical Center, Seongnam, Korea. ${ }^{2}$ School of Medicine, Chosun University, Gwangju, Korea. ${ }^{3}$ Ajou University School of Medicine, Suwon, Korea.

Published: 3 October 2013

doi:10.1186/1687-9856-2013-S1-P15

Cite this article as: Kim et al: Clinical characteristics and laboratory findings of children and adolescents with diabetes. International Journal of Pediatric Endocrinology 2013 2013(Suppl 1):P15.
Submit your next manuscript to BioMed Central and take full advantage of:

- Convenient online submission

- Thorough peer review

- No space constraints or color figure charges

- Immediate publication on acceptance

- Inclusion in PubMed, CAS, Scopus and Google Scholar

- Research which is freely available for redistribution
() Biomed Central
() Biomed Central

C 2013 Kim et al; licensee BioMed Central Ltd. This is an Open Access article distributed under the terms of the Creative Commons Attribution License (http://creativecommons.org/licenses/by/2.0), which permits unrestricted use, distribution, and reproduction in any medium, provided the original work is properly cited. 